\title{
New Records of Marine Diatoms for the American Continent Found on Stone Scorpionfish Scorpaena mystes (Scorpaenidae) in Mexican Shores
}

\author{
Francisco 0. López-Fuerte ${ }^{1}\left(\mathbb{B}\right.$, David A. Siqueiros-Beltrones ${ }^{2^{*}}(\mathbb{B}$, \\ Ulianov Jakes-Cota ${ }^{3}$, Arturo Tripp-Valdéz ${ }^{3}$ \\ ${ }^{1}$ Departamento Académico de Ciencias Marinas y Costeras, Laboratorio de Sistemas Arrecifales, Universidad Autónoma de Baja \\ California Sur, La Paz, México \\ ${ }^{2}$ Departamento de Plancton y Ecología Marina, Centro Interdisciplinario de Ciencias Marinas, Instituto Politécnico Nacional, La \\ Paz, México \\ ${ }^{3}$ Departamento de Pesquerías y Biología Marina, Centro Interdisciplinario de Ciencias Marinas, Instituto Politécnico Nacional, La \\ $\mathrm{Paz}$, México \\ Email: folopez@uabcs.mx, ^dsiquei@gmail.com, ujakes@ipn.mx, atrippv@ipn.mx
}

How to cite this paper: López-Fuerte, F.O., Siqueiros-Beltrones, D.A., Jakes-Cota, U. and Tripp-Valdéz, A. (2019) New Records of Marine Diatoms for the American Continent Found on Stone Scorpionfish Scorpaena mystes (Scorpaenidae) in Mexican Shores. Open Journal of Marine Science, 9 , 98-112.

https://doi.org/10.4236/ojms.2019.92008

Received: March 13, 2019

Accepted: April 14, 2019

Published: April 17, 2019

Copyright $\odot 2019$ by author(s) and Scientific Research Publishing Inc. This work is licensed under the Creative Commons Attribution International License (CC BY 4.0).

http://creativecommons.org/licenses/by/4.0/

\begin{abstract}
The survey of new benthic substrata is expected to yield new records of diatom taxa. A particular type of substratum is the skin of the Stone scorpionfish Scorpaena mystes Jordan \& Starks, 1895 that, because of its benthic form of life, represents a potential colonizing surface for various organisms, including epizoic and opportunistic diatom taxa (epibiotic community). Thus, a floristic survey of diatoms was carried out by sampling the epibiotic community from $S$. mystes specimens collected in the east coast of Baja California Sur (Gulf of California). Thirty diatoms are new records for Mexican littorals. Twelve of these taxa had not been hitherto recorded for American coasts. Micrographs, and morphometric and distribution data on these taxa are provided.
\end{abstract}

\section{Keywords}

Epibiotic, Floristics, Mexican Littorals, Species Richness, Stone Scorpionfish

\section{Introduction}

A recent surge of floristic studies reviews on benthic diatoms from Mexican littorals has yielded an extensive species list [1] that has kept on growing on the 
basis of ex-professo studies, particularly for the Mexican northwestern [2] [3]. In this way, the survey of new substrata in the Mexican coasts promises still more new records of benthic diatom taxa. In particular, live substrata represent a rich source of epiphytic and epizoic diatoms. The latter comprises a wide array of host species that include invertebrates such as copepods, ciliates, bryozoans, hydrozoans, holothurians and vertebrates such as dolphins, whales, manatees and turtles [4] [5]. Out of these, the less studied is fish, and most research has been done on freshwater species [6] [7] [8] [9] [10]. For the marine environment, and in particular for epizoic algae on fish, Ballantine et al. [11] carried out the only study with three species of scorpaenids, recording only ten diatom taxa.

The body form of scorpaenids fishes provides them with camouflage, which is enhanced by skin ornaments, and a brown layer over the skin made from hydrozoans, filamentous algae, diatoms and other organisms that grow mainly on the cephalic region [12]. Thus, the benthic habit of the stone fish Scorpaena mystes Jordan \& Starks, 1895, and its idleness, make it an ideal live substratum for testing various hypothesis on the relation animal host/epizoic diatom, but the scarcity of basic studies such as diatom floristics limits the spectrum of said hypotheses. However, several benefits have been noted for these epizoic diatoms, such as protection against grazing, availability of growing nutritional supplements, and an elevated position that also reduces the risk of being resuspended when growing on sediments [13] [14] [15].

Current observations by the first author of a rich diatom flora found within the epibiotic community growing on $S$. mystes suggested that new taxa could be found on this poorly explored substrate. Thus, the objective of this paper is to report new records of diatom taxa for Mexican waters and the American continent from the epibiotic community of $S$. mystes specimens collected in the central zone of the east coast of the Gulf of California (Santa Rosalia, Baja California Sur).

\section{Materials and Methods}

Twenty scorpion-fish specimens were captured during April 2016 off the coast of Santa Rosalia, Baja California Sur, Mexico which is located at $27^{\circ} 19^{\prime} \mathrm{N}$, $112^{\circ} 15^{\prime} \mathrm{W}$ (Figure 1). Fish specimens were caught manually with hand-held spears using semi-autonomous diving equipment (hookah) at an approximate depth of $20 \mathrm{~m}$. Specimens were identified as $S$. mystes following Grove and Lavenberg [16].

Diatoms and other organisms (macroalgae mainly) were separated from the skin of the fishes using a tooth-brush to generate a compound sample from the twenty specimens. The brushed-off material was placed in a $250 \mathrm{~mL}$ flask and preserved in commercial 70\% ethanol. Afterwards, in order to eliminate organic matter which would preclude visibility of the diatom frustules, the compound sample was oxidized by adding $3 \mathrm{~mL}$ of $70 \%$ nitric acid to $2 \mathrm{~mL}$ of sample, heating with a burner to boiling point and until emission of gas subsided indicating end of 


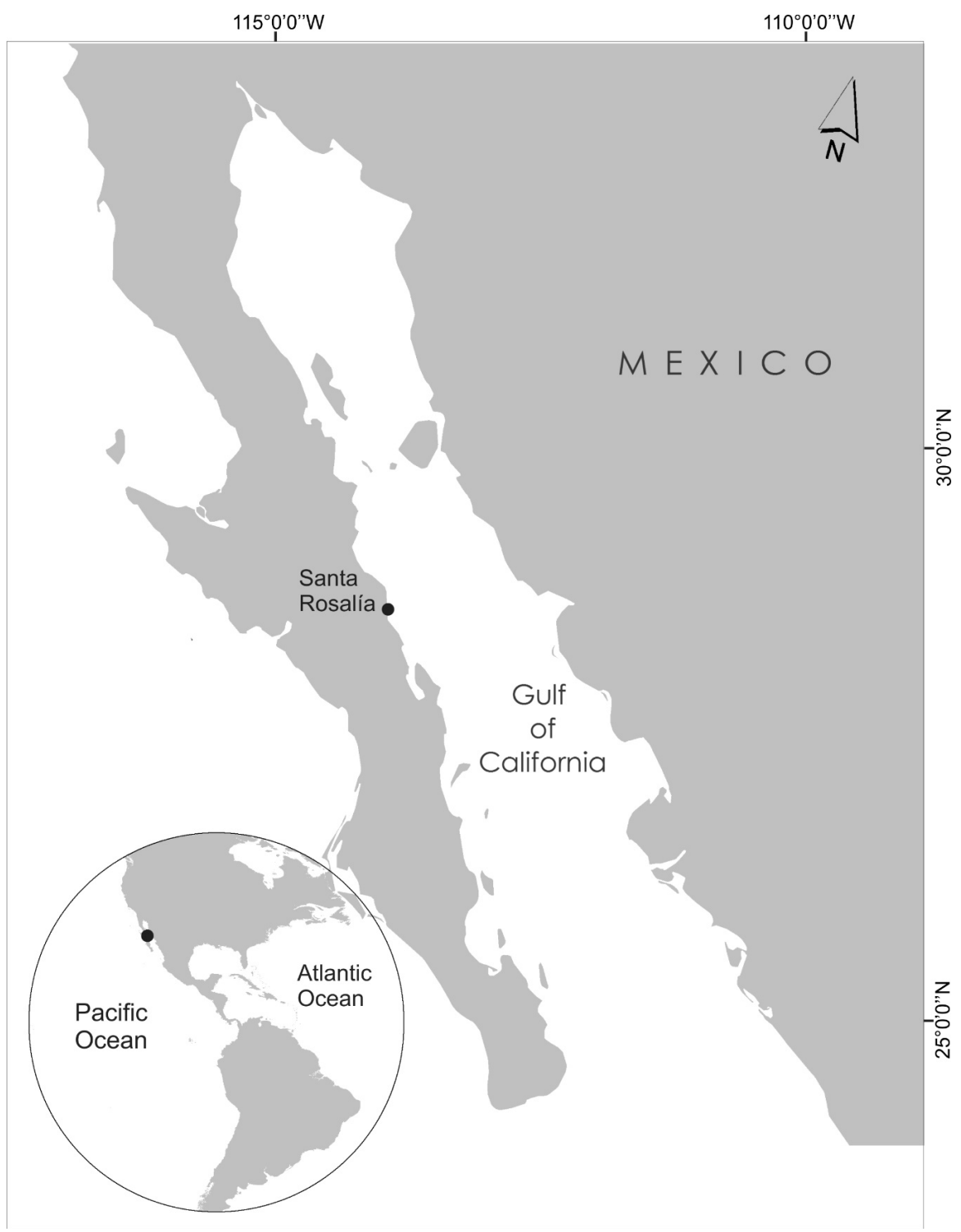

Figure 1. Location of sampling site off Santa Rosalia, Baja California Sur, Mexico.

reaction (ca. $3 \mathrm{~min}$.). The oxidized sample was rinsed repeatedly with purified water until reaching a circumneutral $\mathrm{pH}$. Then, twelve permanent slides were mounted using Zyrax ${ }^{\circledR}(\mathrm{RI}=1.7)$ (made and distributed by Prof. Bill Daily of the University of Pennsylvania).

The mounted slides were observed under a Zeiss ${ }^{\circledR}$ Axio Lab A1 compound microscope (Zeiss, Germany) with phase contrast optics and equipped with a Canon EOS Rebel T5i camera (Canon, Japan). Identification of the taxa was done specifically using the reference that appears in its corresponding description. A formal list of the diatom taxa was constructed following Round et al. [17], and including information on synonymy, references, distribution, and morphometrics, which in several taxa refer to a single found specimen. Nomenclatural updates were done according to AlgaeBase [18], the Catalogue of Diatom Names, California Academy of Sciences 
(http://researcharchive.calacademy.org/research/diatoms/names/index.asp), and http://www.marinespecies.org/ [19].

\section{Results}

Thirty benthic diatom taxa, including species and varieties, are presented here as new records for the Mexican littorals, along with twelve taxa not recorded before for the American continent. These taxa belong to the Bacillariophyceae (21 species), Coscinodiscophyceae (6 species), and Fragilariophyceae (3 species), that comprise nine orders, 14 families and 20 genera, with $30 \%$ of the species belonging to Amphora (6) and Navicula (3).

In what follows, taxonomic data, reference, synonymy, basionym, distribution, morphometric information, and illustrations are provided. Taxa without a previous record in the American continent are designated with an asterisk $\left(^{*}\right)$.

\section{COSCINODISCOPHYCEAE Round \& Crawford}

\section{Order Biddulphiales Krieger}

Family Biddulphiaceae Kützing

Biddulphia juncta (A. Schmidt) A. Mann* (Figure 2M)

Morphometric data. Length $85 \mu \mathrm{m}$; width $78 \mu \mathrm{m}$; 3 areolae in $10 \mu \mathrm{m}$.

Synonyms. Triceratium junctum A. Schmidt, Amphipentas juncta (A. Schmidt) De Toni.

Literature. Schmidt's Atlas [20], pl. 98, Figures 1-3 (as T. junctum A. Schmidt) Distribution. Asia (China, Taiwan and Philippine Islands as T. junctum).

Biddulphiopsis membranacea (Cleve) von Stosch \& Simonsen (Figure 2J) Morphometric data. Length $101 \mu \mathrm{m}$; width $48 \mu \mathrm{m} ; 19$ areolae in $10 \mu \mathrm{m}$.

Basionym. Biddulphia membranacea Cleve.

Literature. Stidolph et al. [20], pl. 21, Figure 7.

Distribution. South America (Colombia, Galapagos Islands), Barbados, Oceania (Guam), West Indian Archipelago and Africa (Mozambique).

Trigonium arcticum (Brightwell) Cleve (Figure 2B)

Morphometric data. Length $111 \mu \mathrm{m}$; width (side) $104 \mu \mathrm{m} ; 19$ areolae in $10 \mu \mathrm{m}$. Synonyms. Triceratium arcticum Brightwell, Biddulphia arctica (Brightwell) Boyer.

Literature. Peragallo \& Peragallo [21], pl. 104, Figure 1. Stidolph et al. [20], pl. 7, Figure 139-140.

Distribution. Asia, Europe, Antarctic and subantarctic islands.

Comments. A marine littoral species, epiphytic or attached to various substrata.

\section{Order Coscinodiscales}

\section{Family Coscinodiscaceae}

Thalassiosira maculata cf. Fryxell \& Johansen (Figures 2C-E)

Morphometric data. diameter $22 \mu \mathrm{m} ; 22$ areolae in $10 \mu \mathrm{m}$.

Literature. Hustedt [22], p. 112, Figures 26-28, Foged [23], pl. 6, Figure 1.

Distribution. Antarctic, Africa. 


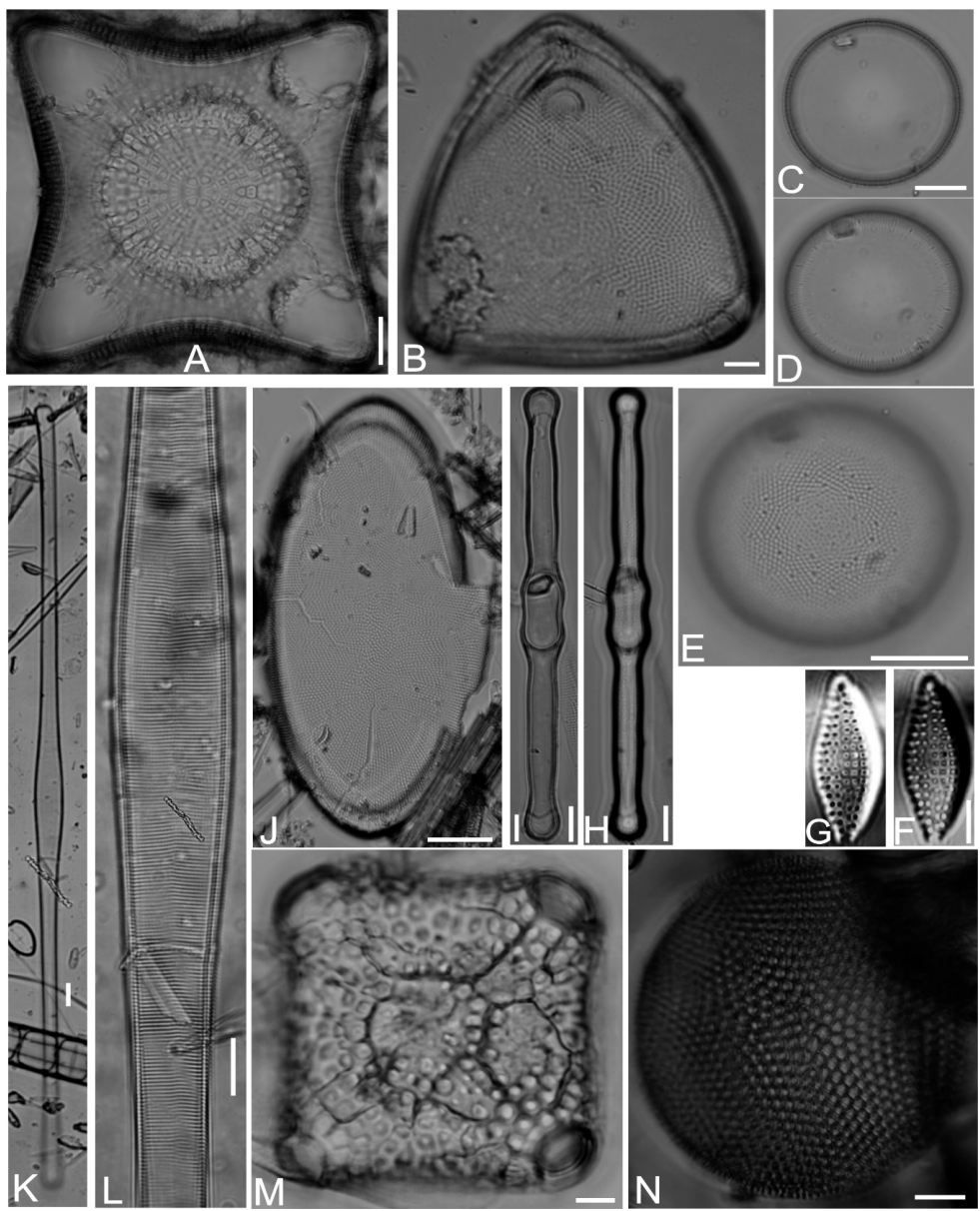

Figure 2. A. Amphitetras subrotundata, B. Trigonium arcticum, C-E. Thalassiosira maculata cf., F-G. Rhaphoneis hungarica, H-I. Grammatophora undulata var. gallopagensis, J. Biddulphiopsis membranacea, K-L. Ardissonea fulgens var. gigantea, M. Biddulphia juncta, N. Shionodiscus bioculatus cf. Scale bar: $10 \mu \mathrm{m}$.

Comments. This taxon is considered to be restricted to the southern hemisphere, frequently found in subantarctic and antarctic waters, becoming more abundant southward.

Shionodiscus bioculatus cf. (Grunow) Alverson, Kang \& Theriot (Figure $2 \mathrm{~N})$

Morphometric data. diameter $70 \mu \mathrm{m} ; 4$ areolae in $10 \mu \mathrm{m}$.

Synonyms. Coscinodiscus bioculatus Grunow, Thalassiosira bioculata (Grunow) Ostenfeld, Coscinosira bioculata (Grunow) H. Heiden.

Literature. Hustedt [24], p. 331, Figure 168.

Distribution. Europe, Asia, Arctic, Canada.

Order Triceratiales Round \& Crawford

Family Triceratiaceae (Schütt) Lemmermann

Amphitetras subrotundata Janisch (Figure 2A)

Morphometric data. Length $80 \mu \mathrm{m}$; width $90 \mu \mathrm{m} ; 4$ areolae in $10 \mu \mathrm{m}$.

Literature. Schmidt's Atlas (1874-1959), pl. 99, Figure 24, Stidolph et al. [20], pl. 5, Figures 108-112. 
Distribution. Asia, Europe, USA, Arctic.

\section{Order Ardissoneales Round}

\section{FRAGILARIOPHYCEAE Round}

Family Ardissoneaceae Round

Ardissonea fulgens var. gigantea (Lobarzewsky) De Toni (Figures 2K-2L)

Morphometric data. Length $340 \mu \mathrm{m}$; width $13 \mu \mathrm{m} ; 18$ striae in $10 \mu \mathrm{m}$.

Synonyms. Synedra gigantea Lobarzewsky.

Literature. Peragallo \& Peragallo [21], pl. 79, Figure 6 [as Synedra fulgens var. gigantea (Lobarzewsky) H. Peragallo \& M. Peragallo], Lobban \& Schefter [20], pl. 1, 16, Figures 1-2, 6-8.

Distribution. South America (Brazil), Oceania (Guam), Gulf of Mexico Krayesky et al. 2009.

\section{Order Rhaphoneidales Round}

Family Rhaphoneidaceae Forti

Rhaphoneis hungarica Pantocsek (Figure 2F \& Figure 2G)

Morphometric data. Length $28.33 \mu \mathrm{m}$; width $9.16 \mu \mathrm{m} ; 8$ - 9 striae radiating in $10 \mu \mathrm{m}$.

Synonyms. Sceptroneis hungarica (Pantocsek) G. Andrews.

Literature. Pantocsek, J. [25], Teil I, p. 34; pl. 3, 25, pl. 25, Figure 224; pl. 3

Figure 30.

Distribution. Europe, USA.

Order Striatellales Round

Family Striatellaceae Kützing

Grammatophora undulata var. gallopagensis Grunow (Figure 2H \& Figure 2I)

Morphometric data. Length $125 \mu \mathrm{m}$; width $11 \mu \mathrm{m}$, Van Heurck [26] report 27 striae in $10 \mu \mathrm{m}$.

Literature. Van Heurck, H. [26], pl. 53 bis, Figure 20.

Distribution. Europe (Belgium).

Comments. In both data bases consulted, AlgaeBase and Worms the status of this taxon is considered uncertain (unassessed).

BACILLARIOPHYCEAE Haeckel

Order Achnanthales Silva

Family Achnanthaceae Kützing

Achnanthes apiculata (Greville) Riaux-Gobin, Compère, Hinz \& Ector*

(Figure 3A \& Figure 3B)

Morphometric data. Length 28 - $47 \mu \mathrm{m}$; width 17 - $26 \mu \mathrm{m}$, Rapheless valve: (9) 11 - 12 striae in $10 \mu \mathrm{m}$, Raphe valve: 18 - 20 striae in $10 \mu \mathrm{m}$.

Synonyms. Stauroneis apiculata Greville

Literature. Riaux-Gobin et al. [27], p. 111; Figures 1, 58-61.

Distribution. USA. Cuba, Africa.

Comments. According to Riaux-Gobin et al. [27] this taxon may belong to the genus, Schizostauron, however, they choose Achnanthes after Ross [28], who 

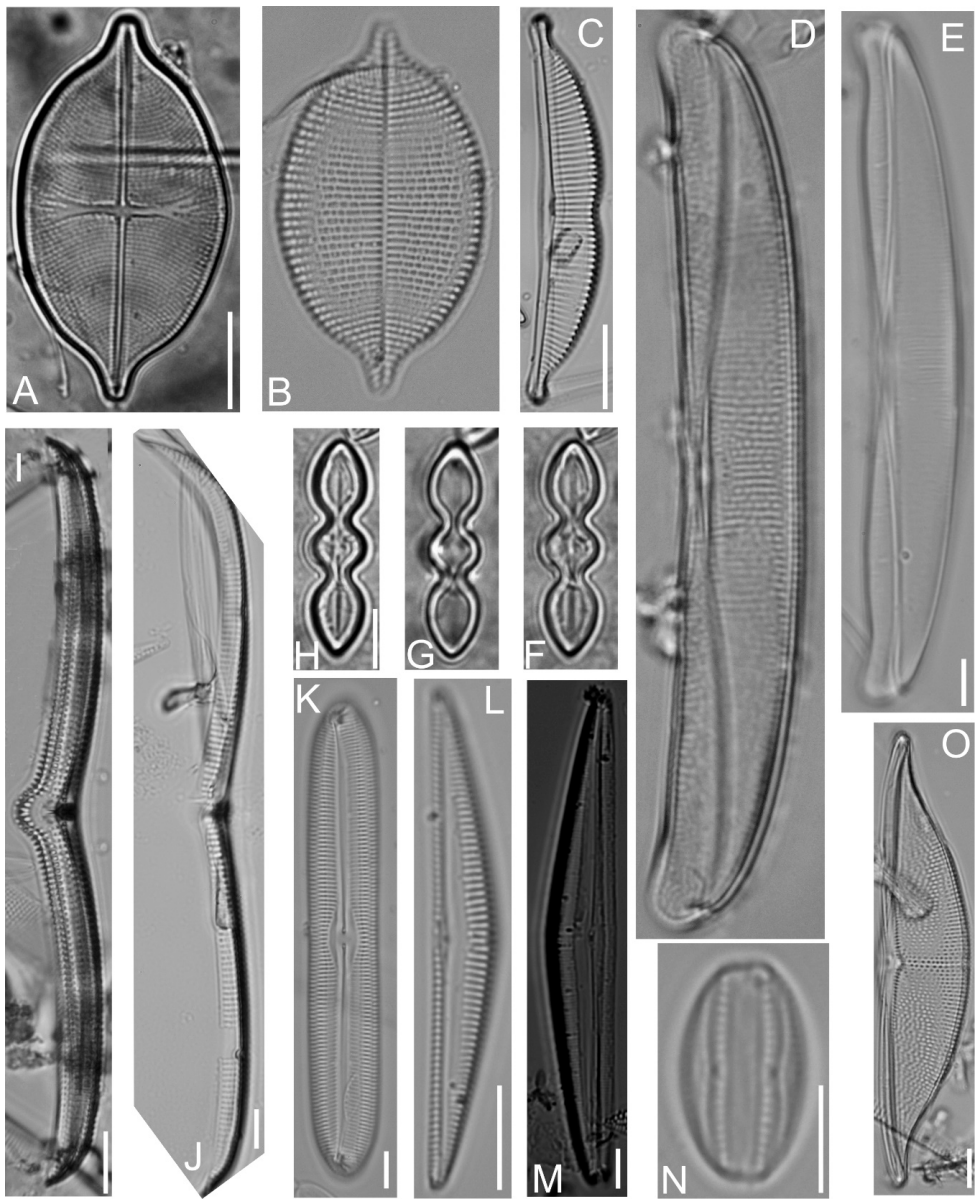

Figure 3. A-B. Achnanthes apiculata, C. Halamphora subangularis cf., D-E. Amphora formosa var. studeri, F-H. Caloneis egena, I-J. Amphora arcus, K. Caloneis liber var. umbilicata cf., L. Amphora cymbamphora, M. Seminavis basilica cf., N. Amphora helenensis, O. Amphora arcuata. Scale bar: $10 \mu \mathrm{m}$.

includes the Schizostauron forms in Achnanthes. Thus, we decided for Achnanthes apiculata, as proposed by Riaux-Gobin et al. [27].

Order Naviculales Bessey

Family Diploneidaceae D. G. Mann

Diploneis ingens (A. Mann) Van Landingham* (Figure 4A)

Morphometric data. Length $105 \mu \mathrm{m}$; width $59 \mu \mathrm{m}$; 7 - 8 striae in $10 \mu \mathrm{m}$.

Synonyms. Navicula ingens Mann.

Literature. Mann, A. [29] p. 105; pl. 22, Figure 8 (as Navicula ingens Mann).

Distribution. Philippine Islands.

\section{Family Amphipleuraceae Grunow}

Halamphora subangularis cf. (Hustedt) Levkov (Figure 3C)

Morphometric data. Length $38 \mu \mathrm{m}$; width $9 \mu \mathrm{m} ; 9$ - 10 dorsal striae in $10 \mu \mathrm{m}$. Synonyms. Amphora subangularis Hustedt.

Literature. Levkov, Z. [30], vol. 5, pl. 110, Figure 15; Hustedt [22], p. 39, pl. 13: 16-17; Simonsen [31], p. 628: 1-2; both as Amphora subangularis Hustedt.

Distribution. Europe, USA. 

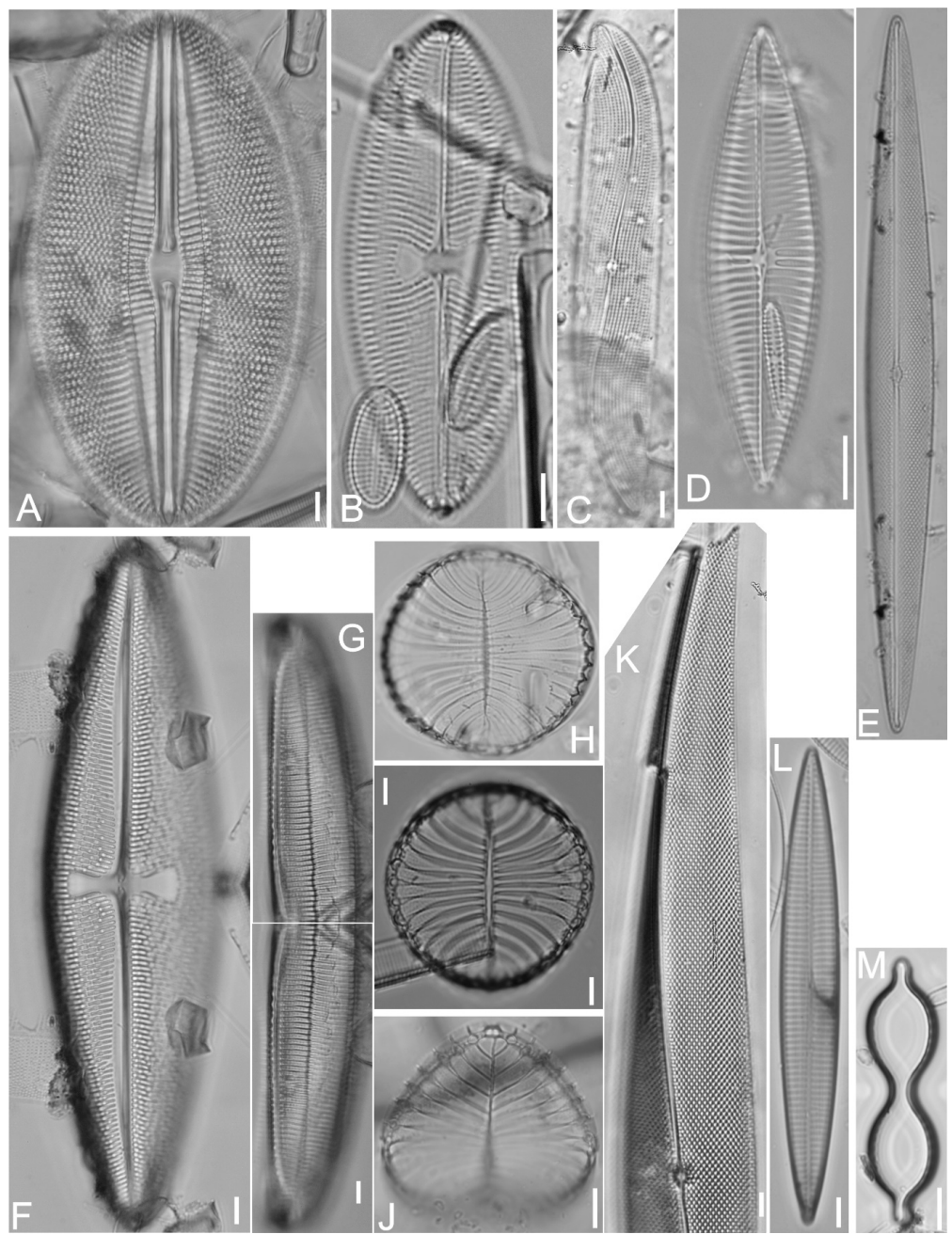

Figure 4. A. Diploneis ingens, B. Trachyneis aspera var. oblonga, C. Gyrosigma hummii, D. Navicula transitans, E. Pleurosigma patagonicum var. paucistriatum, F. Trachyneis aspera var. robusta, G. Amphora compacta, H-J. Coronia decora, K. Pleurosigma delicatulum, L. Navicula halinae, M. N. permulsa (cingular band). Scale bar: $10 \mu \mathrm{m}$.

Comments. Siqueiros Beltrones et al. [32], figure 164, reported a specimen as Amphora angulosa Gregory, albeit for the Pacific coast of the Baja Peninsula that coincides in all morphological traits with Levkov's description and ours. Hustedt's description, however, reports 22 - 23 striae $/ 10 \mu \mathrm{m}$.

Family Diadesmidaceae D. G. Mann

Caloneis egena (A. Schmidt) Cleve (Figures $3 \mathrm{~F}-\mathrm{H}$ )

Morphometric data. Length $25 \mu \mathrm{m}$; width $5.8 \mu \mathrm{m}$.

Synonyms. Navicula egena A. Schmidt.

Literature. Witkowski et al. [33], p. 164, pl. 160, Figures 13-14.

Distribution. Europe, Oceania, Gulf of Mexico, Thailand.

Caloneis liber var. umbilicata cf. (Grunow) Cleve* (Figure 3K)

Morphometric data. Length $145 \mu \mathrm{m}$; width $22 \mu \mathrm{m} ; 10$ striae in $10 \mu \mathrm{m}$.

Basionym. Navicula maxima var. umbilicata Grunow.

Synonyms. Navicula liber var. umbilicata (Grunow) Grunow. 
Literature. Cleve, P. T. [34], 26(2): 1-194, p. 55, pl. 5.

Distribution. Europe, Caribbean sea (Puerto Rico).

Family Naviculaceae Kützing

Navicula halinae Witkowski* (Figure 4L)

Morphometric data. Length $68 \mu \mathrm{m}$; width $8 \mu \mathrm{m}$; 11 - 12 striae in $10 \mu \mathrm{m}$.

Literature. Witkowski et al. [33], p. 281, pl. 130 Figures 1-4.

Distribution. Africa (Atlantic coast of Namibia).

Navicula permulsa Hustedt (Figure 4M)

Morphometric data. Length $60 \mu \mathrm{m}$; width $15 \mu \mathrm{m} ; 5$ - 6 striae in $10 \mu \mathrm{m}$.

Literature. Schmidt's Atlas [35], pl. 394, Figure 22.

Distribution. South America (Galapagos).

Comments. Although only the cingular bands are depicted in the plates, complete valves were observed and measured, but could not be found again for photographic recording.

\section{Navicula transitans Cleve (Figure 4D)}

Morphometric data. Length $75 \mu \mathrm{m}$; width $18 \mu \mathrm{m} ; 7$ - 8 striae in $10 \mu \mathrm{m}$.

Literature. Witkowski et al. [33], p. 309, pl. 127, Figures 6-8.

Distribution. Europe, North America (USA, Canada), Indian Ocean, West Africa and Russia.

Seminavis basilica cf. Danielidis (Figure 3M)

Morphometric data. Length $68 \mu \mathrm{m}$; width $9 \mu \mathrm{m} ; 28$ - 30 dorsal striae in $10 \mu \mathrm{m}$, 30 - 32 ventral striae in $10 \mu \mathrm{m}$.

Literature. Danielidis \& Mann [36], p. 22, Figures 1-19.

Distribution. Europe, USA.

Trachyneis aspera var. robusta (Petit) Cleve* (Figure 4F)

Morphometric data. Length 50 - $62 \mu \mathrm{m}$; width 20 - $25 \mu \mathrm{m} ; 11$ - 12 striae in 10 $\mu \mathrm{m}$.

Synonyms. Stauroneis robusta Petit.

Literature. Peragallo \& Peragallo [21]: p. 151, pl. 29, Figures 8-9 (as Trachyneis robusta Petit).

Distribution. Europe (New Zealand, Italy).

Trachyneis aspera var. oblonga (J. W. Bailey) Cleve (Figure 4B)

Morphometric data. Length $168 \mu \mathrm{m}$; width $39 \mu \mathrm{m} ; 9$ - 10 striae in $10 \mu \mathrm{m}$.

Basionym. Stauroptera oblonga J. W. Bailey.

Synonyms. Trachyneis oblonga (J. W. Bailey) H. Peragallo \& M. Peragallo, Stauroneis oblonga (Bailey) Ralfs.

Literature. Peragallo \& Peragallo [21], p. 192, pls. 25-48.

Distribution. Europe, Asia, Australia, New Zealand, Canada.

Family Pleurosigmataceae Mereschowsky

Gyrosigma hummii Hustedt* (Figure 4C)

Morphometric data. Length $99 \mu \mathrm{m}$; width $17 \mu \mathrm{m}$; 14-15 striae in $10 \mu \mathrm{m}$.

Literature. Hustedt, F. [22], p.33, pl. 10, Figure 2.

Distribution. USA.

Pleurosigma delicatulum W. Smith* (Figure 4K) 
Morphometric data. Length $226 \mu \mathrm{m}$; width $26 \mu \mathrm{m} ; 10$ - 11 striae in $10 \mu \mathrm{m}$.

Synonyms. Gyrosigma delicatulum (W. Smith) Griffith \& Henfrey, Pleurosigma angulatum var. delicatulum (W. Smith) van Heurck.

Literature. Peragallo \& Peragallo [21], p. 166, pl. 32, Figures 14-15.

Distribution. Europe, USA, Canada, South America (Brazil, Colombia) Africa, Asia.

Pleurosigma patagonicum (Ferrario \& Sar) Sterrenburg \& Sar var. paucistriatum Sar, Sterrenburg \& Sunesen (Figure 4E)

Morphometric data. Length $128 \mu \mathrm{m}$; width $12 \mu \mathrm{m} ; 20$ - 21 transversal striae in $10 \mu \mathrm{m}, 16$ - 17 oblique striae in $10 \mu \mathrm{m}$.

Literature. Sar, E. U, Sterrenburg, F.A.S., A. S. Lavigne \& I. Sunesen [37]. Bol. Soc. Argent. Bot. 48(1): 17-51.

Distribution. South America (Argentina).

Order Surirellales

Family Surirellaceae Kützing

Coronia decora (Brébisson) Ruck \& Guiry (Figure 4H \& Figure 4J)

Morphometric data. Length $34 \mu \mathrm{m}$; width $35 \mu \mathrm{m} ; 7$ - 8 ribs in $10 \mu \mathrm{m}$.

Synonyms. Campylodiscus decorus Brébisson.

Literature. Witkowski et al. [33], p. 412, pl. 214, Figure 15, Stidolph (1980), p. 403, pl. 14, Figure 10; Lobban et al. [38], p. 469, pl. 64, Figures 5-6 (in all cases as C. decorus Brébisson).

Distribution. Europe, USA, South America, Asia, Oceania.

Order Thalassiophysales D. G. Mann

Family Catenulaceae Mereschkowski

Amphora arcus Gregory* (Figure 3I \& Figure 3J)

Morphometric data. Length 116 - $121 \mu \mathrm{m}$; width 5 - $9 \mu \mathrm{m} ; 11$ - 13 striae in 10 $\mu \mathrm{m}$.

Literature. Sensu Witkowski et al. [33], p. 129, pl. 165 Figure 15.

Distribution. Europe.

Amphora arcuata A. Schmidt (Figure 30)

Morphometric data. Length $75 \mu \mathrm{m}$; width $13 \mu \mathrm{m}$; 15 - 16 striae in $10 \mu \mathrm{m}$.

Synonyms. Amphora acuta var. arcuata (A. Schmidt) Cleve.

Literature. Schmidt et al. [35], pl. 26, Figures 27-29; Peragallo \& Peragallo [21], pl. 49, Figures 27, 28.

Distribution. Europe, USA, Oceania, Puerto Rico, Virgin Islands.

Amphora compacta A. Mann* (Figure 4G)

Morphometric data. Length $174 \mu \mathrm{m}$; width $26 \mu \mathrm{m}$; 7 - 8 dorsal striae in $10 \mu \mathrm{m}$, 8 - 9 ventral striae in $10 \mu \mathrm{m}$.

Literature. Mann, A. [29], p. 19; pl. 3, Figure 6.

Distribution. Philippine Islands.

\section{Amphora cymbamphora Cholnoky* (Figure 3L)}

Morphometric data. Length $9 \mu \mathrm{m}$; width $5 \mu \mathrm{m}$; 14 dorsal striae in $10 \mu \mathrm{m}, 15$ 16 ventral striae in $10 \mu \mathrm{m}$. 
Literature. Witkowski et al. [33], p. 136, pl. 164, Figures 26-28.

Distribution. Oceania, South Africa, Baltic Sea.

Amphora formosa var. studeri Janisch* (Figure 3D \& Figure 3E)

Morphometric data. Length 71 - $89 \mu \mathrm{m}$; width 9 - $13 \mu \mathrm{m}$; 14 dorsal striae in 10 $\mu \mathrm{m}, 13$ - 14 ventral striae in $10 \mu \mathrm{m}$.

Basionym. Amphora studeri Janisch

Literature. Peragallo \& Peragallo [21], p. 214; pl. 47, Figure 18.

Distribution. Europe.

Amphora helenensis Giffen (Figure 3N)

Morphometric data. Length $12 \mu \mathrm{m}$; frustule width $9 \mu \mathrm{m}$; valve width $3 \mu \mathrm{m} ; 20$

- 21 dorsal striae in $10 \mu \mathrm{m}, 18$ - 19 ventral striae in $10 \mu \mathrm{m}$.

Literature. Witkowski et al. [33], p. 140, pl. 163, Figures 31-33.

Distribution. Europe, South Africa, Atlantic, Canada, Oceania.

\section{Discussion}

The relative high number of new records for Mexican littorals and those that are new for the whole American continent (12), indicate that much work is yet to be done on floristics of benthic marine diatom. Thus, further surveys that include new substrata where these microalgae may thrive will eventually yield a reliable basis to undertake related studies on ecology and biogeography, both at regional and at worldwide scale. A balance between these findings and an analysis of the overall species richness currently underway, will surely permit addressing questions such as, are exclusively epizoic diatom aggregations lacking on these fish? What characteristics favor the establishment of unique epizoic diatom aggregations? And, how do these rich diatom aggregations compare floristically with hosts from other localities?

Due to the relevance currently recognized on biodiversity data in terms of conservation policy and potential anthropogenic impact in Mexico and worldwide, species inventories are regaining attention. Studies on benthic diatoms, and in particular those on benthic forms, exhibit an underestimation of their geographic distribution, both regionally and worldwide, that is a function of the lack of research, which undermines the reliability of biogeographical analyses [34]. For example, Biddulphia juncta (A. Schmidt) A. Mann (Figure 2M), Achnanthes apiculata (Greville) Riaux-Gobin, Compère, Hinz \& Ector (Figure 3A, Figure 3B), Diploneis ingens (Mann) Van Landingham (Figure 4A), Amphora compacta A. Mann (Figure 4G), and Navicula permulsa Hustedt (Figure 4J) had been recorded for a single continent. Several of these for the Philippine Islands, bringing into mind the observation by Mann [29] on the striking similarity between the diatom flora of these islands and the coasts of Campeche, Mexico. His main concern was the remoteness and isolation between these localities. Our study poses similar questions which require ex-professo biogeographical theory.

Derived from this and other recent efforts on the floristics of benthic diatoms from Mexican coasts, the list of new records incorporated to the overall checklist 
by López-Fuerte and Siqueiros-Beltrones [1] has increased substantially up to 88 from 2013 to 2017, and to 329 new regional records for the coasts of the Baja California Peninsula from 1999 to date. On a worldwide basis these inventories account for just $>1 \%$ of the total diatoms recorded for the whole planet, and around 3.3\% of the species recorded for Mexico [1] [36] [37]. Thus, if we considered that most of the littorals in Mexico have not been surveyed for benthic diatoms, it is to be expected that the species richness is considerably higher. This may be supported by the fact that the recent new records mentioned above originate from previously unexplored areas, such as the Mexican Caribbean [12] [38] and from the Mexican NW [2] [3] [39], as well as from unexplored substrata such as blades of the kelp Eisenia arborea Areschoug [32].

\section{Conclusion}

The new records of taxa collected from the skin of the stonefish in this study are more indicative of scarce floristic research than as representatives of an epizoic relation, i.e. a product of an increasing survey comprising many more substrates and regions. Also, they inhabit a compound substrate where the main component is the skin of the fish, but other forms such as macroalgae and invertebrates are surely attached to it and diatoms to them, thus making up an epibiotic community. Moreover, many of the recorded taxa have been observed on other substrata elsewhere and may not be considered epizoic sensu stricto but are opportunistic as are the general natures of benthic diatoms. Notwithstanding the later, said taxa have not hitherto been recorded elsewhere for Mexican littorals and constitute new additions to the benthic diatom flora of the region, inasmuch as many of the recorded taxa have been observed on other substrata found elsewhere.

\section{Acknowledgements}

We acknowledge the support given by the Universidad Autónoma de Baja California Sur, for the processing of the samples. FOLF thanks the support of the SNI-CONACYT Programs. The second author (DASB) is COFAA and EDI fellow of the Instituto Politécnico Nacional.

\section{Conflicts of Interest}

The authors declare no conflicts of interest regarding the publication of this paper.

\section{References}

[1] López-Fuerte, F.O. and Siqueiros-Beltrones, D.A. (2016) A Checklist of Marine Benthic Diatoms (Bacillariophyta) from México. Phytotaxa, 283, 201-258. https://doi.org/10.11646/phytotaxa.283.3.1

[2] Estrada-Gutiérrez, K.M., Siqueiros-Beltrones, D.A. and Hernández-Almeida, O.U. (2017) New Records of Benthic Diatoms (Bacillariophyceae) for Mexico in the Nayarit Littoral. Revista Mexicana de Biodiversidad, 88, 985-987. 
https://doi.org/10.1016/j.rmb.2017.10.039

[3] Siqueiros-Beltrones, D.A. and Argumedo-Hernández, U. (2017) New Records of Benthic Marine Diatom Taxa for Mexican Littorals. CICIMAR Oceánides, 32, 59-62.

[4] Tiffany, M.A. (2011) Epizoic and Epiphytic Diatoms. In: Seckbach, J. and Kociolek, J.P., Eds., The Diatom World, Springer, New York, 197-209. https://doi.org/10.1007/978-94-007-1327-7_8

[5] Robinson, N.J., Majewska, R., Lazo-Wasem, E.A., Nel, R., Paladino, F.V., Rojas, L., Zardus, J.D. and Pinou, T. (2016) Epibiotic Diatoms Are Universally Present on All Sea Turtle Species. PLoS ONE, 11, e0157011. https://doi.org/10.1371/journal.pone.0157011

[6] Vinyard, W.C. (1953) Epizoophytic Algae from Mollusks, Turtles, and Fish in Oklahoma. Proceedings of the Oklahoma Academy of Science, 34, 63-65.

[7] Nigrelli, R.F., McLaughlin, J.J. and Jakowska, S. (1958) Histozoic Algal Growth in Fish. Copeia, 4, 331-333. https://doi.org/10.2307/1439971

[8] Hoffman, G.L. (1976) Parasites of North American Freshwater Fishes. University California Press, Berkeley, 486 p.

[9] Miller, J.W. and Ballantine, D.L. (1972) Opercular Algal Growth on the Cichlid Fish Tilapia aurea Cultured in Sea Water. Aquaculture, 4, 93-95. https://doi.org/10.1016/0044-8486(74)90024-6

[10] Millstein, J. (1998) Observations of Skin Sloughing in the Crested Sculpin (Blepsias bilobus). Copeia, 3, 743-745. https://doi.org/10.2307/1447807

[11] Ballantine, D.L., Navarro, J.N. and Hensley, D.A. (2001) Algal Colonization of Caribbean Scorpionfishes. Bulletin of Marine Science, 69, 1089-1094.

[12] Fishelson, L. (1973) Observations on Skin Structure and Sloughing in the Stone Fish Synanceja verrucosa and Related Fish Species as a Functional Adaptation to Their Mode of Life. Zeitschrift fur Zellforschung und Mikroskopische Anatomie, 140, 497-508. https://doi.org/10.1007/BF00306676

[13] Round, F.E. (1981) The Ecology of Algae. Cambridge University Press, Cambridge, $653 \mathrm{p}$.

[14] Gaevskii, N.A., Kolmakov, V.I., Dubovskaya, O.P. and Klimova, E.P. (2004) Interrelations of Epibiontic Microalgae and Crustacean Zooplankton under Conditions of a Blooming Eutrophic Water Body. Russian Journal of Ecology, 35, 35-41. https://doi.org/10.1023/B:RUSE.0000011107.72097.1c

[15] Romagnoli, T., Bavestrello, G., Cucchiari, E., De Stefano, M., Di Camillo, C., Pennesi, C., Puce, S. and Totti, C. (2007) Microalgal Communities Epibiontic on the Marine Hydroid Eudendrium racemosum in the Ligurian Sea, during an Annual Cycle. Marine Biology, 151, 537-552. https://doi.org/10.1007/s00227-006-0487-x

[16] Grove, J.S. and Lavenberg, R.J. (1997) The Fishes of the Galápagos Islands. Stanford University Press. Stanford, $863 \mathrm{p}$.

[17] Round, F.E., Crawford, R.M. and Mann, D.G. (1990) The Diatoms. Cambridge University Press, Cambridge, 747 p.

[18] Guiry, M.D. and Guiry, G.M. (2019) Algaebase. World-Wide Electronic Publication. National University of Ireland, Galway. http://www.algaebase.org

[19] WoRMS Editorial Board (2019) World Register of Marine Species. http://www.marinespecies.org

[20] Stidolph, S.R., Sterrenburg, F.A.S., Smith, K.E.L. and Kraberg, A. (2012) Stuart R. 
Stidolph Diatom Atlas. U.S. Geological Survey Open-File Report. http://pubs.usgs.gov/of/2012/1163

[21] Peragallo, H. and Peragallo, M. (1897-1908) Diatomées Marines de France et des Districts Maritimes Voisins. In: Tempère, J., Ed., Micrographe-Editeur, à Grez-sur-Loing, $491 \mathrm{p}$.

[22] Hustedt, F. (1955) Marine Littoral Diatoms of Beaufort, North Carolina. Vol. 6, Bulletin Duke University Marine Station, Duke University Press, Durham, 1-67.

[23] Foged, N. (1975) Some Littoral Diatoms from the Coasts of Tanzania. Cramer. Vaduz, $127 \mathrm{p}$.

[24] Hustedt, F. (1930) Bacillariophyta (Diatomeae). In: Pascher, A., Ed., Die Süsswasser-Flora Mitteleuropas, Gustav Fischer, Jena. Zweite Auflage. Heft 10. 466 p.

[25] Pantocsek, J. (1886) Beiträge zur Kenntnis der Fossilen Bacillarien Ungarns. Teil I, Marine Bacillarien. Nagy-Tapolcsány, Buchdrucherei von Julius Platzko, 74 p. https://doi.org/10.5962/bhl.title.14916

[26] Van Heurck, H. (1880) Synopsis des Diatomées de Belgique. Atlas. Ducaju \& Cie, Anvers, Belgium, $120 \mathrm{p}$.

[27] Riaux-Gobin, C., Compère, P., Hinz, F. and Ector, L. (2015) Achnanthes citronella, A. trachyderma comb. nov. (Bacillariophyta) and Allied Taxa Pertaining to the Same Morphological Group. Phytotaxa, 227, 101-119. https://doi.org/10.11646/phytotaxa.227.2.1

[28] Ross, R. (1963) The Diatom Genus Capartogramma and the Identity of Schizostauron. Bulletin of the British Museum of Natural History, Botany, 3, 47-92.

[29] Mann, A. (1925) Marine Diatoms of the Philippine Islands. Bulletin of the United States National Museum, 6, 1-182.

[30] Levkov, Z., Krstic, S., Metzeltin, D. and Nakov, T. (2007) Diatoms of Lakes Prespa and Ohrid (Macedonia). Iconographia Diatomologica, 16, 1-613.

[31] Simonsen, R. (1962) Untersuchungen zur Systematik und Ökologie der Bodendiatomeen der westlichen Ostsee. Internationale Revue der Gesamten Hydrobiologie, Systematische, Beihefte, 1, 1-144.

[32] Siqueiros-Beltrones, D.A. and Argumedo-Hernández, U. (2014) Quasi Monospecific Proliferation of Pteroncola inane (Giffen) Round (Fragilariales; Bacillariophyceae) on Blades of Eisenia arborea Areschoug. CICIMAR Oceánides, 29, 57-62.

[33] Witkowski, A., Lange-Bertalot, H. and Metzeltin, D. (2000) Diatom Flora of Marine Coasts. In: Lange-Bertalot, H., Ed., Iconographia Diatomologica, Koeltz Scientific Books, Königstein, 1-925.

[34] Vanormelingen, P., Cottenie, K., Michels, E., Muylaert, K., Vyverman, W. and de Meester, L. (2008) The Relative Importance of Dispersal and Local Processes in Structuring Phytoplankton Communities in a Set of Highly Interconnected Ponds. Freshwater Biology, 53, 2170-2183.

[35] Schmidt, A., Schmidt, M.V., Fricke, F.V., Heiden, H., Muller, O. and Hustedt, F. (1874-1959) Atlas der diatomaceenkunde, Heft 1-120, Tafeln 1-460. Reisland, Leipzig.

[36] Fourtanier, E. and Kociolek, J.P. (2017) Catalogue of Diatom Names, California Academy of Sciences.

http://research.calacademy.org/research/diatoms/names/index.asp

[37] Mann, D.G. (1999) The Species Concept in Diatoms. Phycologia, 38, 437-495. https://doi.org/10.2216/i0031-8884-38-6-437.1

[38] López-Fuerte, F.O., Siqueiros-Beltrones, D.A. and Hernández-Almeida, O.U. (2013) 
Epiphytic Diatoms of Thalassia testudinum in Yala-hau Lagoon, Quintana Roo, Mexico. Marine Biodiversity Records, 6, e107.

https://doi.org/10.1017/S1755267213000857

[39] López-Fuerte, F.O., Siqueiros-Beltrones, D.A. and Yabur, R. (2015) First Record of Benthic Diatoms (Bacillariophyceae and Fragilariophyceae) from Isla Guadalupe, Baja California, México. Revista Mexicana de Biodiversidad, 86, 281-292.

https://doi.org/10.1016/j.rmb.2015.04.016 